\title{
The RelationshipBetween Entrepreneurship Education And Mentoring Toward Entrepreneurship Intention
}

\author{
Elisse Natalia and Sabrina O. Sihombing \\ Business SchoolUniversitasPelitaHarapan, Tangerang \\ Email:sabrina.sihombing@uph.com
}

\begin{abstract}
This study aims to determine the relationship between factors that influence entrepreneurial intentions which consist of entrepreneurship education, entrepreneurial attitudes, subjective norms, self efficacy, and mentoring. Research on factors that influence entrepreneurship has been carried out by many previous researchers. However, mentoring is a variable that is rarely studied in previous studies. This study will discuss more about the variable mentoring. In this study, the quantitative paradigm was used as the basis of this study, with the type of descriptive research. The object of research used is the entrepreneurship study program. While the analysis unit used is an individual. Data collection methods in the form of questionnaires with 24 indicators with an interval measurement scale that is a 5-point Likert scale. The sampling design used is nonprobability sampling, namely judgment sampling with students and students majoring in entrepreneurship as active as a sample. The number of samples used in this study is 85 for preliminary studies, and 157 for actual research studies. After the data is collected, the data is then tested for reliability and validity using Cronbach's Alpha and construct validity using Pearson Correlation and also Exploratory Factor Analysis (EFA). After passing the reliability and validity tests, of the 24 indicators used previously, only 15 indicators met the requirements for reliability testing and validity testing. Then the data was then analyzed using PLS-SEM. The results of this study are from eight predetermined hypotheses, there are two hypotheses that are not supported by several reasons. From this study, it can be concluded that there is no relationship between entrepreneurial education and student self-efficacy, and the absence of a relationship between mentoring and student self-efficacy.
\end{abstract}

Keywords: entrepreneurship education, attitude toward entrepreneurship, subjective norms, self-efficacy, entrepreneurship intention, mentoring

\section{BACKGROUND}

Unemployment has become a problem for many countries, including Indonesia. This is because the high labour force is not matched by an increase in the number of jobs (Adnyana and Purnami, 2016). The workforce is also required to have a good quality of self in order to be able to compete for limited employment, so that higher education becomes very important because it is considered capable of creating quality human resources. However, data obtained from the Central Bureau of Statistics (BPS, 2017) shows that the number of graduates of unemployed diplomas is 249,705 and the graduate degree is 606,939 . This shows that higher education does not necessarily guarantee someone to get a job.

One of the right solutions to overcome unemployment in Indonesia is to increase entrepreneurs. With the increasing number of entrepreneurs in Indonesia, this means that 
new jobs will also increase. As a result, unemployment in Indonesia can be reduced. In recent years there have been many studies conducted on the relationship between entrepreneurial education and entrepreneurial intentions. Entrepreneurial attitudes, subjective norms and self-efficacy are some of the variables that are often examined in research regarding the relationship between entrepreneurial education and entrepreneurial intentions. But there have not been many studies discussing mentoring or mentoring in entrepreneurship education. In fact, mentoring can be considered as an important part of the entrepreneurial learning process and contributors to the improvement of learning outcomes (Kubberoed and Hagen, 2015). Therefore, this study was conducted to examine further the role of entrepreneurial education in enhancing student entrepreneurial intentions in Indonesia, by including variables of mentoring, entrepreneurial attitudes, subjective norms, and self-efficacy. This study uses the object of the entrepreneurship study program in order to provide solutions to the problems that occur.

\section{LITERATURE REVIEW}

Entrepreneurship. Entrepreneurship is defined as the process by which individuals pursue opportunities regardless of resources that are currently controlled with the aim of creating goods and services in the future (Barringer and Ireland, 2015). Budy (2017) said that entrepreneurship arises when someone dares to develop new businesses and ideas. Entrepreneurship requires creativity, innovation, risk taking, and planning to achieve the desired goals (Weber et al, 2014; Barringer and Ireland, 2015). People who run entrepreneurship are known as entrepreneurs. According to Barringer and Ireland (2015) entrepreneurship can be interpreted as a person who collects and integrates all the needed resources such as money, human resources, business models, strategies and the ability to bear the risk to transform a creation into a new business.

Theory of Planned Behavior. The theory of planned behavior is a renewal of the theory of reasoned action proposed by Ajzen and Fishbein. The reasoned action theory assumes that behavior arises on the basis of an individual's desire or intention to do or not to conduct a certain behavior or vice versa (Mahyarni, 2013). Furthermore, Ajzen and Fishbein explained that intentions are determined by subjective attitudes and norms. According to Ajzen (2005) attitude is a tendency to respond positively and negatively to an object, person, institution or event. While subjective norm refers to social pressure that is felt by someone to do or not to do a behavior (Ajzen, 2015).Ajzen (2015) then developed a theory of reasoned action into a theory of planned behavior. In the theory of planned behavior, added constructs that do not yet exist in the theory of reasoned action, namely perceived behavioral control or known as self-efficacy. Fishbein and Ajzen define behavioral controls that are perceived as people's perceptions of their level of ability to do things.

Entrepreneurship Intention. Literally, intention has the same meaning as intention. Ajzen (2012) argues that intention is an antecedent of behavior. Intention is a behavioral tendency that will be manifested in the form of action (Ajzen, 2005). The intention of entrepreneurship can be defined as a person's tendency to take advantage of existing business opportunities to create something new. Entrepreneurial intention reflects a person's commitment to start a new business and is a central issue that needs to be 
considered in understanding the entrepreneurial process of establishing a new business (Azwar, 2013). In the theory of planned behavior, it is believed that attitude factors, subjective norms, and self-efficacy will shape one's intentions and then will directly influence behavior. Therefore an understanding of entrepreneurial intentions reflects an individual's tendency to establish a real business.

Entrepreneurship Education. Understanding of entrepreneurship is very important in order to create potential entrepreneurs. According to Fatoki (2014), business school is a bridge between theoretical knowledge and practical involvement in the field. Chimucheka (2013, in Adnyana and Purnami, 2016), states that one of the factors driving entrepreneurial growth in a country lies in the role of universities through the implementation of entrepreneurial education. Entrepreneurship education can be defined as academic education or formal training interventions that aim to provide an entrepreneurial mindset and expertise to individuals to support participation and performance in various entrepreneurial activities (Valerio et al, 2014). In general, entrepreneurship education aims to increase awareness of entrepreneurship as a career choice and increase understanding of the process of establishing and managing a new business (Arasti et al, 2012). However, entrepreneurial education is not just about teaching about how to run a business, but also encouraging creative thinking and increasing selfesteem and accountability (Fatoki, 2014).

Entrepreneurship Attitude.Schiffman and Wisenblit (2015) define attitude as a tendency to behave well or not consistently with an object. Basically a person tends to accept or reject an object based on an assessment of the object (Schwarz, 2007 in Kusmintarti et al, 2017). Attitude is an evaluative response, meaning that the form of the reaction expressed by the attitude arises based on the evaluation process in the individual that gives a conclusion to the stimulus in the form of good-bad, positive-negative, pleasant-unpleasant, which then crystallizes as a potential reaction to object of attitude (Borasi and Finnigan, 2010, in Kusmintarti et al, 2017). Hidayah (2015) defines entrepreneurial attitudes as a tendency to react effectively to the risks that will be faced in business. Entrepreneurial attitudes act as agents of change that affect productivity and profitability (Borasi and Finnigan, 2010, in Kusmintarti et al, 2017).

Subjective Norm.Ajzen (2015) defines subjective norms as social pressure that a person feels to do or not to conduct a behavior. Subjective norm is an individual belief function in terms of agreeing or disagreeing with something, which is based on a belief called normative beliefs (Mahyarni, 2013). Ajzen (2015) defines normative beliefs as perceived and perceived behavior of individuals or groups of referents, which are combined with one's motivation to comply with the referent concerned. A person will have a desire for an object or behavior if he is affected by those around him to do it or he believes that the environment or the people around him support what he does (Maskur et al, 2015).

Self-efficacy. Efficacy plays a very important role in everyday life. A person will be able to use his potential optimally when his self-efficacy supports (Rustika, 2012). Selfefficacy is people's trust in their ability to achieve something (Bandura, 2012). Someone who believes that they can do something that has the potential to change events in the environment tends to actually act and is more likely to succeed than someone with low self-efficacy (Feist et al, 2013). Self-efficacy in entrepreneurship concerns a person's trust 
in his ability to build and run a business. Personal perception like this plays an important role in developing one's intentions. Therefore, in entrepreneurship a person needs to have self-efficacy towards his entrepreneurial ability so that his business becomes successful.

Mentoring. Mentoring is defined as guidance from someone who masters certain things that are shared with others who need them (Pramudianto, 2015, 10). Federal (2008, in Sulung, 2016) defines mentoring in more detail, namely as a process in which an individual who has experience or expertise gives more encouragement, advice, and support to a less experienced colleague, with the aim of helping people who are being guided something. From this definition it can be concluded that there are two parties involved in the mentoring process namely mentors and mentees. A mentor is a facilitator who works with an individual or group of people (mentee) over a long period of time (Sulung, 2016). Mentors strive to build wisdom of the ability to apply skills, knowledge and experience to new situations (Michael, 2008 in Sulung, 2016). Mentors, both formal and informal, contribute to the overall development of the individual but with emphasis on different development categories (Bruce and Bridgeland, 2014, 23).

\section{Variables Relationship and the Research Model}

Entrepreneurship Education and Entrepreneurial Intention. Entrepreneurship education is an important factor in growing and developing entrepreneurial desire, soul and behavior (Fatoki, 2014: 295). Based on research conducted by Adnyana and Purnami (2016), entrepreneurship education has a positive and significant effect on students' entrepreneurial intentions. Research conducted by Wibowo and Pramudana (2016) also shows the same results. Other studies showing similar results are shown by Karimiet al, (2016); Zhang et al., (2014); Hussain and Norashidah (2015); and Fatoki (2014). Based on the previous research, it can be hypothesized that there is a positive relationship between entrepreneurial education and student entrepreneurial intentions.

$\mathbf{H}_{1}$ :There is a positive relationship between entrepreneurial education and entrepreneurial intention.

Entrepreneurship Education and Entrepreneurship Attitudes.In entrepreneurship education, students are not only taught about the concept of entrepreneurship but are also trained to shape the attitude, behavior, and mindset of an entrepreneur. Therefore, entrepreneurship education is considered to be able to positively increase students' entrepreneurial attitudes (Hattab, 2014). The results of research conducted by Yaqub et al (2015) show that entrepreneurship education in the campus environment has a positive effect on entrepreneurial attitudes. Such results are also shown in research conducted by Wibowo and Pramudana (2016). Based on the research, it can be hypothesized that entrepreneurship education has a positive influence on entrepreneurial attitudes. The same results are shown by research conducted by Hajrah, Siswoyo, and Rahayu (2016); Kusmintarti (2016); Mamuasi (2010); Nugrohoet al (2017); Jain (2013); and Prihantoro and Hadi (2016). Based on the previous research, it can be hypothesized that there is a positive relationship between entrepreneurial education and entrepreneurial attitudes.

$\mathbf{H}_{2}$ : There is a positive relationship between entrepreneurial education and entrepreneurial attitude. 
Entrepreneurship Attitude and Entrepreneurial Intention. In the theory of reasoned action and the theory of planned behavior, attitude is considered as one of the factors that influence a person's intention to conduct a behavior. The results of research conducted by Wibowo and Pramudana (2016) show that entrepreneurship attitudes variables have a significant positive effect on entrepreneurial intentions and the role of entrepreneurial attitudes is able to mediate entrepreneurship education towards entrepreneurial intentions. Research conducted by Santi, Hamzah and Rahmawati (2017) also shows the same results, namely that entrepreneurial attitudes have a positive effect on entrepreneurial intentions. This result is in line with previous studies, such as research conducted by Sabah (2016); Soon, Ahmad, and Ibrahim (2014); Astuti and Martdianty (2012); Mwiya et al (2017); Wach and Wojciechowski (2016); Naia et al (2017); and Utami (2017). Based on the previous research, it can be hypothesized that there is a positive relationship between entrepreneurial attitudes and entrepreneurial intentions.

$\mathbf{H}_{3}$ :There is a positive relationship between entrepreneurial attitudes and entrepreneurial intention.

Entrepreneurship Education and Subjective Norms. A person will have a desire for an object or behavior if he is affected by those around him to do it or he believes that the environment or the people around him support what he does (Maskur et al, 2015). In carrying out its education, students and students will interact with friends and lecturers in the entrepreneurship study program. This shows that the environment in which students and students undergo entrepreneurship study programs can be a referent group that influences the subjective norms of students and students majoring in entrepreneurship. The research conducted by Liñán (2004) shows that entrepreneurship education has a significant positive effect on subjective norms. Entrialgo and Iglesias (2016) also stated the relationship between entrepreneurial education and subjective norms. Based on the previous research, it can be hypothesized that entrepreneurship education has a positive influence on subjective norms. Hattab (2014) also carried out the same research with the results that entrepreneurship education has a positive relationship with subjective norms.

H4:There is a positive relationship between entrepreneurial education and subjective norms.

Subjective Norms and Intention to Entrepreneurship. Subjective norms are a person's perception of a decision in carrying out a behavior obtained from social influence. A person will have a desire for an object or behavior if he is affected by those around him to do it or he believes that the environment or the people around him support what he does (Maskur et al, 2015). In the theory of planned behavior, subjective norms are one of the factors that influence a person's intention to conduct a behavior. Therefore, subjective norms are considered to be one of the factors that can influence entrepreneurial intentions. The results of research conducted by Wedayanti and Giantari (2016) show that subjective norms have a positive and significant effect on entrepreneurial intentions. The results of research conducted by Santi et al (2017) also produced the same thing, namely that subjective norms have a positive effect on entrepreneurial intentions. Research conducted by Sabah (2016) also shows a positive and significant influence between subjective norms and entrepreneurial intentions. Similar results are also shown by other studies such as research conducted by Soon et al (2016); Astuti and Martdianty (2012); Mwiya et al (2017); Wach and Wojciechowski (2016); and Utami (2017). Based on the previous 
research, it can be hypothesized that there is a positive relationship between subjective norms and student entrepreneurial intentions.

H5:There is a positive relationship between subjective norms and entrepreneurial intention.

Entrepreneurship and Self-efficacy Education. In carrying out entrepreneurship education, students will be equipped with knowledge and expertise related to entrepreneurship. One source of student self-efficacy is mastery experience (Bandura, 1997, in Feist et al. 2013). If a student feels that he has mastered the knowledge and expertise needed to run his own business, the student's self-efficacy can increase. Cooper and Lucas (2006) and Kilenthong et al (2008) conducted research on entrepreneurship education and self-efficacy and concluded that entrepreneurship education has a positive effect on self-efficacy. In addition, the results of research conducted by Setiawan (2014), Oyugi (2016) and Azizahet al, (2017) also show that entrepreneurship education has a positive effect on self-efficacy. Based on these previous studies, the hypothesis can be drawn that entrepreneurship education has a positive effect on self-efficacy.

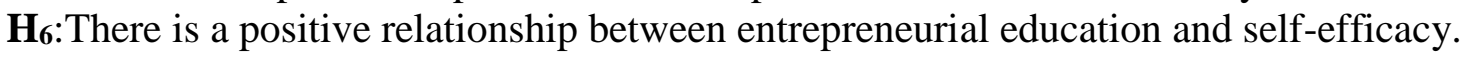

Mentoring and Self-Efficacy. Mentors, both formal and informal, contribute to the overall development of the individual but with emphasis on different development categories (Bruce and Bridgeland, 2014: 23). Liñán (2004: 4) assumes that the existence of a mentor will be a determining element in shaping the level of feasibility perceived by individuals, which in this case is self-efficacy. Hayes (1998), Neal (2008), Feldman et al, (2010), Ljungberg (2011), DeFreitas and Bravo (2012), Flood (2012), Jnah and Robinson (2015), Ismail et al, (2015), and Jain, Chaudhary, and Jain (2016) conducted research on mentoring and self-efficacy relationships. The results of the study indicate that the two variables have a positive relationship. However, in the context of entrepreneurial education, not many studies have been conducted regarding the relationship between these two variables. Santosa and Natsir (2015) conducted a study on the relationship between mentoring and student self-efficacy. The results obtained indicate that mentoring is positively related to entrepreneurial self-efficacy. Furthermore, the results of the study stated that lecturers or universities that carry out entrepreneurship learning with an emphasis on the mentoring process will increase student self-efficacy.

H7:There is a positive relationship between mentoring and self-efficacy.

Self-Efficacy and Intention to Entrepreneurship. People who have high self-efficacy are more likely to set challenging goals and maintain a strong commitment to them (Hayden, 2014: 15). Personal perception like this plays an important role in developing one's intentions (Indarti and Rostiani, 2008, 6). Therefore, self-efficacy is one of the factors that influence entrepreneurial intentions. Based on research conducted by Adnyana and Purnami (2016), self-efficacy has a positive and significant effect on students' entrepreneurial intentions. Research conducted by Jaya and Seminary (2016) also shows that self-efficacy has a significant positive effect on entrepreneurial intentions. The same results are shown by research conducted by Sabah (2016), namely the existence of a positive and significant influence between self-efficacy and entrepreneurial intentions. Many other studies also show similar results, such as research conducted by Soon, Ahmad, and Ibrahim (2016); Astuti and Martdianty (2012); Mwiya, Wang, Shikaputo, Kaulungombe, and Kayakesi (2017); Wach and Wojciechowski (2016); Naia, Baptista, 
Biscaia, Januario, and Trigo (2017); and Utami (2017). Based on the previous research, it can be hypothesized that self-efficacy has a positive effect on entrepreneurial intentions.

Hs: There is a positive relationship between self-efficacy and entrepreneurial intention.

Based on 8 hypotheses that have been discussed previously, the following research model is proposed.

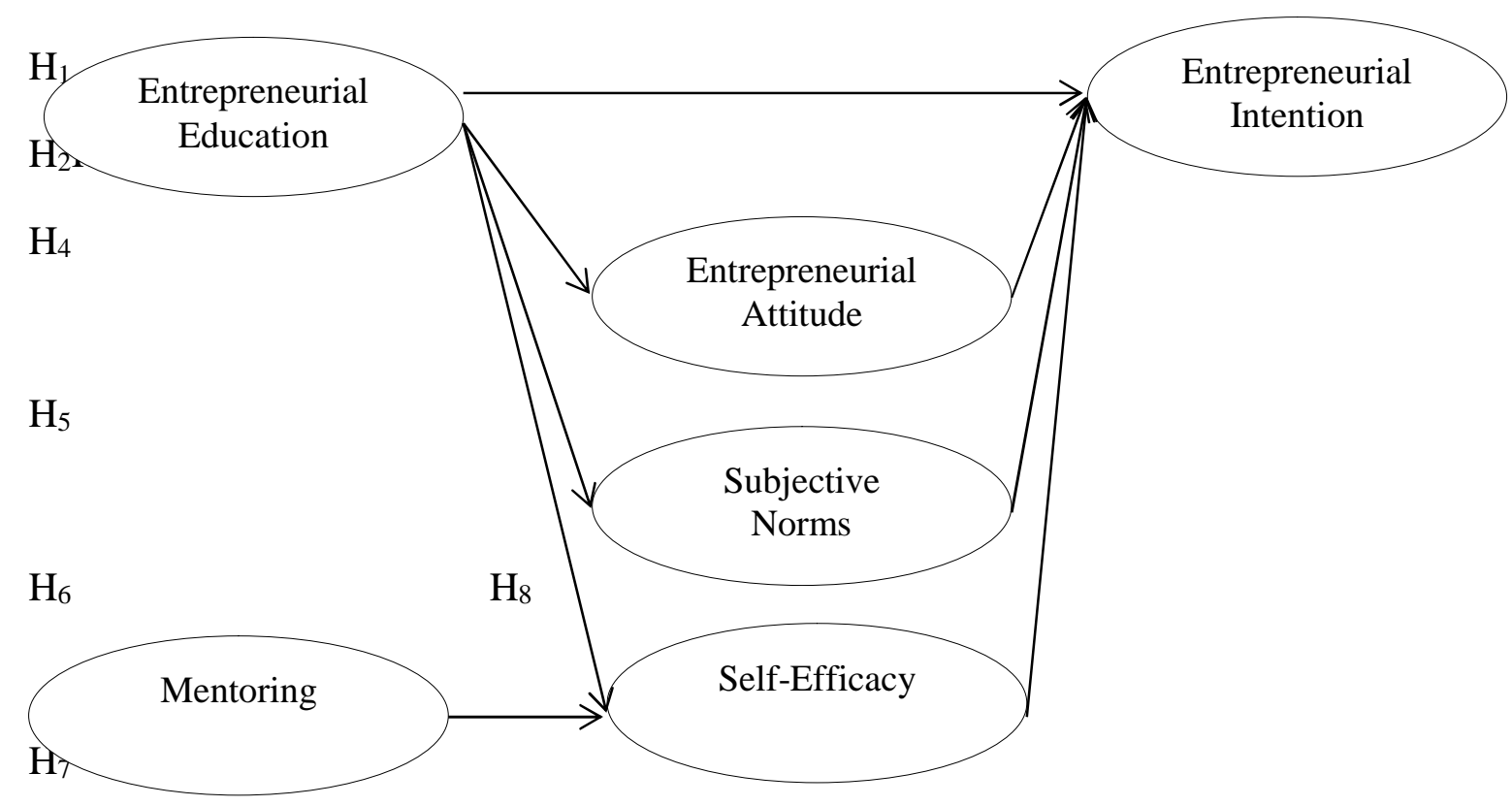

Figure 1. Research Model

Source: developed for this study (2017)

\section{METHODS}

Research Paradigm and Design. This research is quantitative research. The quantitative paradigm in this study aims to provide an overview of the influence of certain treatments / treatments on others, test existing research hypotheses and to provide accurate data, based on empirical and measurable phenomena (Sugiyono, 2014). While the research design in this chapter is descriptive, which is done to explain the existence of relationships between variables (Sekaran and Bougie, 2013, 97), to test the existing hypothesis (Hair et al, 2015), and to explain the relationship between variables with an existing hypothesis.

Conceptual Definitions and Operational Definitions. Entrepreneurial intention is defined as a person's tendency to take advantage of existing business opportunities to create something new (Barringer and Ireland, 2015, 28; Ajzen, 2005, 99). In this study, entrepreneurial intentions were measured using 4 indicators, namely "My goal is to become an entrepreneur", "I will make every effort to establish my own business", "I 
decided to make my own business in the future," and "I have serious thoughts about how to start a business."

Entrepreneurship education is defined as academic education or formal training interventions that aim to provide entrepreneurial mindset and expertise to individuals to support participation and performance in various entrepreneurial activities (Valerio et al, 2014). The indicator used in this study to measure entrepreneurial education is "I obtain knowledge related to entrepreneurship in courses in the entrepreneurship management study program", "The courses in the entrepreneurship management study program improve my skills in preparing business proposals", "Courses in the entrepreneurial management study program encouraged me to participate in business, "and" The courses in the entrepreneurial management study program helped me socialize the mindset of entrepreneurs. "Entrepreneurial attitudes can be interpreted as a tendency to behave well or not consistently with entrepreneurship (Schiffman and Wisenblit, 2015). In this study 4 indicators were used to measure entrepreneurial attitudes, namely "I feel interested in the existing business opportunities", "I have a creative mindset in entrepreneurship", "I have an innovative mindset in entrepreneurship," and "I avoid risk in entrepreneurship. "

Subjective Norms are social pressures that a person feels to do or not to conduct a behavior (Ajzen, 2015). The indicator used to measure is "My friends support me to become an entrepreneur", "My lecturers support me to become an entrepreneur", "My family supports me to become an entrepreneur," and "The person I consider important support me to become an entrepreneur. "Self-efficacy can be defined as a person's confidence that he has the ability to do a behavior (Feist et al, 2013). The indicators used to measure self-efficacy in this study are "I am confident in my leadership abilities", "I believe I can start my own business", "I feel I have the ability to manage a business," and "I believe that my ability to manage a business will bring my business to run smoothly. Mentoring is a transformational process in the form of regular guidance with the aim of helping individuals develop and use knowledge to improve their abilities (Bayley et al, 2016). To measure it, 4 indicators were used, namely "Business mentoring lecturers carry out their roles as mentors", "Mentors provide new insights into running a business", "Mentors tell their entrepreneurial experiences," and "Mentors provide social support by providing assistance in overcoming problem in entrepreneurship. "

Sampling. The subjects used in this study were students of entrepreneurship management study programs in 3 private universities with active status of 157 students. In designing the sampling in this study, non-probability sampling design techniques were used. Furthermore, the non-probability sampling technique used in this study is sampling decision (judgmental sampling). In sampling the decision of members of the population who are the subject of the sample must meet certain requirements (Sekaran and Bougie, 2013). In choosing a sample in this study the conditions used are students and students majoring in entrepreneurship who become the sample must be active, or not taking college leave. The scale used in this study is interval scale with Likert scale method to measure the answers given by respondents in the questionnaire.

Preliminary Study (Pilot study).Prior to conducting actual research a preliminary study is needed (McDaniel and Gates, 2014). According to McBurney and White (2009, in Gunadi and Sihombing, 2015), at the time the research had obtained the indicators to be used in the research, it was necessary to conduct a preliminary study. Furthermore, this 
preliminary study was conducted to ensure that the indicators obtained were in accordance with the research objectives (Gunadi and Sihombing, 2015: 158). In the preliminary study, this study tested the reliability and validity of the indicators used in this study. This study uses 85 respondents to conduct preliminary studies, which are then tested for reliability and validity. This study uses internal consistency reliability testing. Reliability testing was carried out with Cronbach's alpha coefficient. In testing the Cronbach's alpha coefficient, the measuring limit used is 0.7 (Gunadi and Sihombing, 2015).

Validity is the level at which what researchers want to measure is truly measurable (McDaniel and Gates, 2014). According to McDaniel and Gates (2014), the validity of a measuring instrument shows how far the measurement instruments and procedures are free from systematic and random errors. The validity used in this study is construct validity, by measuring convergent and discriminant validity. In this study, convergent validity was carried out by exploratory factor analysis (EFA). The next step is to test discriminant validity. Discriminant validity can be tested through correlation tests (Zikmund and Babin, 2015; Thomas et al, 2010, in Gunadi and Sihombing, 2015, 158). In conducting correlation testing, this study used a correlation limit of 0.75 (Zikmund and Babin, 2015).

Data analysis. The data in this study were analyzed using Structural Equation Modeling (SEM) based on PLS. Structural Equation Modeling (SEM) is a statistical method designed to test a conceptual or theoretical model to explore and confirm the causal relationship between variables (Stufflebeam and Zhang, 2017). Furthermore, this allows researchers to simultaneously test a series of dependency relationships between measured variables and latent variables (variables) as well as between latent variables. In SEM testing, two tests were carried out, namely model measurement testing and structural model testing.

The first test is testing the measurement model. The measurement model connects indicators with variables (Monecke and Leisch, 2012). This first test is done by examining the reliability and validity of measuring instruments based on certain criteria based on the specifications of the model being tested, whether reflective or formative (Hair, Ringle and Marko Sarstedt, 2011). In this study the measurement model used is a reflective measurement model. Reflective models are tested based on their reliability and validity. Construction reliability testing is focused on composite reliability as an estimate of construct or variable internal consistency (Hair et al., 2011). Furthermore, Hair, Ringle and Sarstedt (2011) explained that in contrast to Cronbach's alpha, composite reliability does not assume that all indicators are equivalent to reliability, so that they are suitable for PLS-SEM, which prioritizes indicators based on reliability when the model is tested. Composite reliability is said to be good if it has a value between 0.7 and 0.9 (Hair et al, 2011). In addition to composite reliability, indicator reliability must also be taken into account, where absolute standardized loading each indicator must be higher than 0.7 .

Testing the validity of the reflective measurement model focuses on convergent and discriminant validity (Hair et al, 2011). Furthermore, to test the convergent validity studied is average variance extracted (AVE). AVE values of 0.5 and above indicate a sufficient level of convergent validity, which means that the latent variable explains more than half the variance of the indicators. As for testing discriminant validity, two criteria are used: (1) the Fornell-Larcker criteria and (2) cross-loadings. According to Fornell and Larcker (1981, in Hair, Ringle and Marko Sarstedt, 2011, 145) the construct or latent variable shares more variance with its indicators than with other latent variables in the 
structural model. AVE each construct or latent variable must be higher than the highest squared correlation of the latent variable with other latent variables. The second criterion is to look at cross loadings, where loading an indicator with the latent variable reflected must be higher than loading the indicator with other variables.

The structural model shows the relationship between constructs or variables (Hair et al., 2011). The main structural model testing criteria are squared correlation (R2) and the level and significance of path coefficients. According to Hair et al.,(2011: 147) high R2 values depend on research discipline. Furthermore, for disciplines such as consumer behavior, 0.20 is considered high. This research is included in disciplines that are similar to consumer behavior, because it is used to assess that R2 0.20 is considered high. The significance of the path coefficients indicates that the research hypothesis is supported. In this study the level of significance used is 5 percent (0.05) so that the critical t-values used as limits are \pm 1.96 (Hair, Ringle and Marko Sarstedt, 2011: 145). In other words, the relationship between variables is said to be significant if the p-value does not exceed 0.05 and the critical $\mathrm{t}$-value is not between -1.96 and +1.96 .

\section{RESULTS}

Measurement Model. In testing the measurement model through PLS-SEM, what must be done is to test internal consistency reliability, indicator reliability, convergent validity and discriminant validity.

Tabel 1. Internal Consistency Reliability Test Results

\begin{tabular}{lcc}
\hline & Composite Reliability & Requirements \\
\hline Entrepreneurship Intention & 0.889 & $0.7<\mathrm{CR}<0.9$ \\
Entrepreneurship Education & 0.869 & $0.7<\mathrm{CR}<0.9$ \\
Entrepreneurship Attitude & 0.894 & $0.7<\mathrm{CR}<0.9$ \\
Subjective Norm & 0.891 & $0.7<\mathrm{CR}<0.9$ \\
Self-efficacy & 0.892 & $0.7<\mathrm{CR}<0.9$ \\
Mentoring & 0.888 & $0.7<\mathrm{CR}<0.9$ \\
\hline
\end{tabular}

Source: data analysis (2017)

In testing the reliability of internal consistency in the measurement model, the requirements that must be fulfilled are the value of composite reliability must be between 0.7-0.9. Based on the results shown in Table 2, composite reliability of all variables has met the specified requirements.

Tabel 2. Reliability Indicator Test Results

\begin{tabular}{lcc}
\hline & Indicator Loading & Requirements \\
\hline SE_2 <- SE & 0.939 & $>0.7$ \\
SE_3 - SE & 0.907 & $>0.7$ \\
IB_1 <- IB & 0.794 & $>0.7$ \\
IB_2 <- IB & 0.880 & $>0.7$ \\
IB_3 - IB & 0.882 & $>0.7$ \\
M_1 <- M & 0.806 & $>0.7$ \\
M_2 <- M & 0.863 & $>0.7$ \\
\hline
\end{tabular}




\begin{tabular}{ccc}
\hline M_3 <- M & 0.800 & $>0.7$ \\
M_4 <- M & 0.792 & $>0.7$ \\
EI_1 <-SN & 0.917 & $>0.7$ \\
SN_2 <- SN & 0.903 & $>0.7$ \\
EE_2 <- EE & 0.851 & $>0.7$ \\
EE_4 <- EE & 0.901 & $>0.7$ \\
EA_2 <- EA & 0.907 & $>0.7$ \\
EA_3 - EA & 0.943 & $>0.7$ \\
\hline
\end{tabular}

Source: data analysis (2017)

In testing the reliability of the indicator, the indicator loadings must be above 0.7 . In the table it can be seen that the reliability of each indicator has met the specified requirements. Indicator loading on the reliability test results of this indicator ranges from 0.791 to 0.943 .

Tabel 3.Converging Reliability Test Results (AVE)

\begin{tabular}{lcc}
\hline & Average Variance Extracted & Persyaratan \\
\hline Entrepreneurship Intention & 0.728 & $>0.5$ \\
Entrepreneurship Education & 0.768 & $>0.5$ \\
Entrepreneurship Attitude & 0.856 & $>0.5$ \\
Subjective Norm & 0.828 & $>0.5$ \\
Self-efficacy & 0.852 & $>0.5$ \\
Mentoring & 0.665 & $>0.5$ \\
\hline
\end{tabular}

Source: data analysis (2017)

In testing the convergent reliability of the measurement model, the requirement that must be met is the average variance extracted (AVE) value must be above 0.5. Based on the results presented in Table $4 \mathrm{a}$, it can be seen that AVE of each variable exceeds 0.5. In other words, AVE each variable has fulfilled the specified requirements.

Table 4a. Discriminant Validity Test Result

\begin{tabular}{lllllll}
\hline & ED & M & IB & NS & PK & SK \\
\hline ED & $\mathbf{0 . 9 2 3}$ & & & & & \\
M & 0.301 & $\mathbf{0 . 8 1 6}$ & & & & \\
IB & 0.447 & 0.374 & $\mathbf{0 . 8 5 3}$ & & & \\
NS & 0.307 & 0.389 & 0.594 & $\mathbf{0 . 9 1}$ & & \\
PK & 0.302 & 0.650 & 0.522 & 0.399 & $\mathbf{0 . 8 7 7}$ & \\
SK & 0.5 & 0.451 & 0.570 & 0.523 & 0.46 & $\mathbf{0 . 9 2 5}$ \\
\hline
\end{tabular}

Source: data analysis (2017)

Table 4b. Discriminant Validity Test Result

\begin{tabular}{lllllll}
\hline & SE & IB & M & SN & EE & EA \\
\hline SE_2 & $\mathbf{0 . 9 3 9}$ & 0.445 & 0.309 & 0.303 & 0.314 & 0.518 \\
ED_3 & $\mathbf{0 . 9 0 7}$ & 0.374 & 0.239 & 0.261 & 0.237 & 0.394 \\
IB_1 & 0.291 & $\mathbf{0 . 7 9 4}$ & 0.224 & 0.431 & 0.293 & 0.386 \\
\hline
\end{tabular}




\begin{tabular}{lllllll}
\hline IB_2 & 0.401 & $\mathbf{0 . 8 8 0}$ & 0.449 & 0.536 & 0.56 & 0.531 \\
IB_3 & 0.433 & $\mathbf{0 . 8 8 2}$ & 0.258 & 0.541 & 0.445 & 0.521 \\
M_1 & 0.208 & 0.318 & $\mathbf{0 . 8 0 6}$ & 0.348 & 0.53 & 0.325 \\
M_2 & 0.276 & 0.317 & $\mathbf{0 . 8 6 3}$ & 0.358 & 0.594 & 0.369 \\
M_3 & 0.27 & 0.234 & $\mathbf{0 . 8}$ & 0.264 & 0.453 & 0.333 \\
M_4 & 0.213 & 0.37 & $\mathbf{0 . 7 9 2}$ & 0.305 & 0.552 & 0.454 \\
SN_1 & 0.271 & 0.581 & 0.352 & $\mathbf{0 . 9 1 7}$ & 0.344 & 0.42 \\
SN_2 & 0.288 & 0.498 & 0.356 & $\mathbf{0 . 9 0 3}$ & 0.384 & 0.536 \\
EE_2 & 0.317 & 0.398 & 0.566 & 0.276 & $\mathbf{0 . 8 5 1}$ & 0.357 \\
EE_4 & 0.223 & 0.509 & 0.575 & 0.412 & $\mathbf{0 . 9 0 1}$ & 0.443 \\
EA_2 & 0.513 & 0.456 & 0.397 & 0.41 & 0.374 & $\mathbf{0 . 9 0 7}$ \\
EA_3 & 0.424 & 0.585 & 0.435 & 0.544 & 0.469 & $\mathbf{0 . 9 4 3}$ \\
\hline
\end{tabular}

Source: data analysis (2017)

The requirement of testing the first discriminant validity is the value of squared correlation of each construct or latent variable higher than the squared correlation construct with other latent constructs. In table 5a it can be seen that discriminant validity has been achieved. The second condition is loadings each latent construct indicator must be higher than the entire cross loadings of the indicator concerned. In Table $4 \mathrm{~b}$ it can be seen that these conditions have been reached. With the achievement of these two conditions, it can be said that discriminant validity has been achieved.

Structural Model. After testing the measurement model, structural models were tested. A hypothesis will be supported if there is a significant relationship between variables, namely if it has a critical value of \pm 1.96 . This value is obtained from table $Z$, and is determined by the level of significance used in this study. The significance level applied in this study is $5 \%$ or 0.05 . The results of testing hypotheses with structural models can be seen in Table 6.

Table 5. Structural Test Results Model

\begin{tabular}{|c|c|c|c|c|c|}
\hline Hypothesis & $\begin{array}{c}\text { Variable } \\
\text { Relationships }\end{array}$ & $\begin{array}{c}\text { Standardized } \\
\text { regression } \\
\text { weight } \\
\end{array}$ & $\begin{array}{c}\text { Critical } \\
\text { Value }\end{array}$ & p-value & Conclusion \\
\hline $\mathrm{H}_{1}$ & $\begin{array}{l}\text { Entrepreneurship } \\
\text { Education } \rightarrow \text { Entrep } \\
\text { reneurship } \\
\text { Intention }\end{array}$ & 0.245 & 3.685 & $* * *$ & Supported \\
\hline $\mathrm{H}_{2}$ & $\begin{array}{l}\text { Entrepreneurship } \\
\text { Education } \rightarrow \text { Entrep } \\
\text { reneurship } \\
\text { Attitude }\end{array}$ & 0.460 & 5.512 & $* * *$ & Supported \\
\hline $\mathrm{H}_{3}$ & $\begin{array}{l}\text { Entreprenurship } \\
\text { Attitude } \rightarrow \text { Entrepre } \\
\text { neurship Intention } \\
\text { Entrepreneurship }\end{array}$ & 0.191 & 2.388 & 0.017 & Supported \\
\hline $\mathrm{H}_{4}$ & $\begin{array}{l}\text { Education } \rightarrow \text { Subje } \\
\text { ctive Norm } \\
\text { Subjective }\end{array}$ & 0.399 & 4.082 & $* * *$ & Supported \\
\hline $\mathrm{H}_{5}$ & $\begin{array}{l}\text { Norm } \rightarrow \text { Entreprene } \\
\text { urship Intention }\end{array}$ & 0.344 & 3.967 & $* * *$ & Supported \\
\hline
\end{tabular}




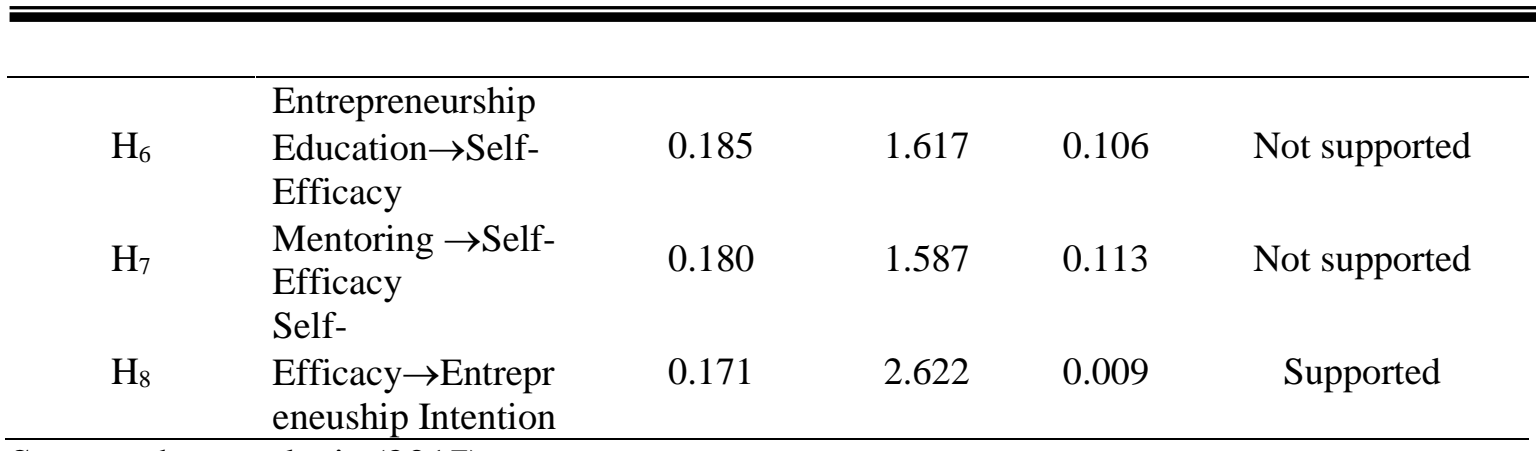

Source: data analysis (2017)

Note: $* * *=\mathrm{P}<0.001$

Based on Table 5, it can be seen that there are six supported hypotheses and two unsupported hypotheses. Indications of a hypothesis supported or not can be seen from the critical value and p-value, where the limit for the critical value is \pm 1.96 and the $p$-value limit is .050.05. From these results the hypotheses supported are H1, H2, H3, H4, H5, H6, and H8. While the unsupported hypothesis is H7. The results of the measurement model and structural model can be seen in Figure 2.

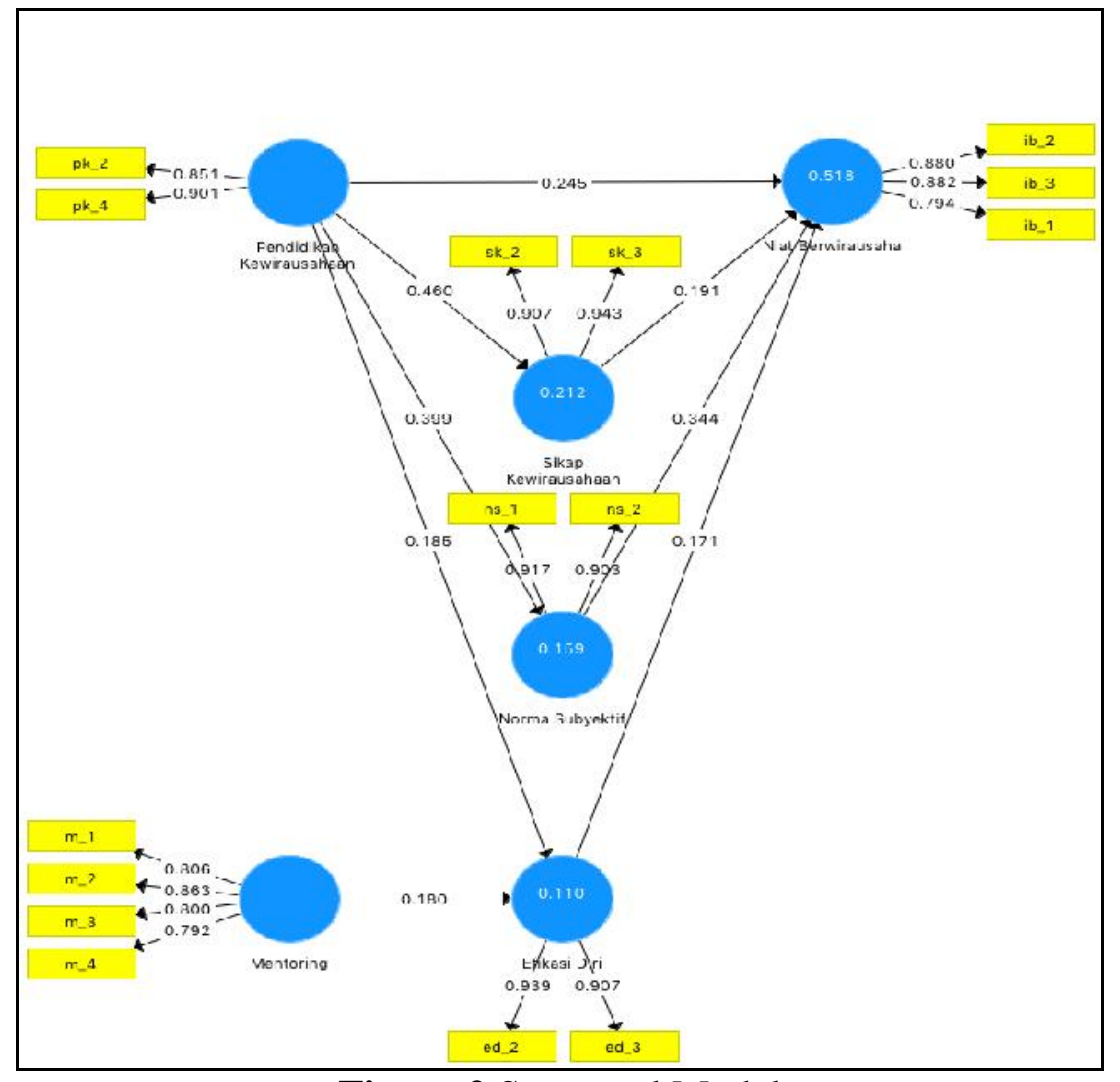

Figure 2.Structural Model

From Figure 2 it can be seen that there is a number 0.851 in the entrepreneurial education arrow towards PK_2. This value of 0.851 indicates that the entrepreneurship education variable can be represented by PK_2 indicator of $85.1 \%$. Then in each endogenous latent variable there is a number indicating the value of $\mathrm{R} 2$. Table 6 describes the endogenous 
latent variables in this study along with the R-Square (R2) value of each endogenous latent variable.

Table 6. Value of R-Square (R2)

\begin{tabular}{lc}
\hline \multicolumn{1}{c}{ Variable } & Value of R-Square (R2) \\
\hline Entrepreneurship Attitude & 0.212 \\
Subjective Norm & 0.159 \\
Self-efficacy & 0.110 \\
Entrepreneurship Intention & 0.518 \\
\hline
\end{tabular}

Source: data analysis (2017)

Discussion.From the results of actual data processing, the regression coefficient value (R2) for the entrepreneurship attitude variable is 0.212 , which means that variations in entrepreneurial attitudes can be explained by entrepreneurship education by $21.2 \%$ while the remaining $78.8 \%$ is influenced by other variables not included in the research model. The $\mathrm{R} 2$ value for the subjective norm variable is 0.159 . This value shows that the variation of subjective norms can be explained by entrepreneurship education by $15.9 \%$ while the rest that is equal to $84.1 \%$ is influenced by other variables not found in the research model. The self efficacy variable has a R2 value of 0.110 , which means that variations in the value of self-efficacy can be explained by entrepreneurship education and mentoring by $11 \%$ while the other $89 \%$ are explained by other variables not included in the research model. Finally, the entrepreneurship intention variable has a R2 value of 0.518 , which means that entrepreneurial intentions can be explained by the variables of entrepreneurial attitudes, subjective norms, and self-efficacy by $51.8 \%$ while the other $48.2 \%$ are explained by other variables not included in this research model. The criteria set to assess $\mathrm{R} 2$ in this study is that if the value of $\mathrm{R} 2$ is greater than 0.2 then it is considered strong. Therefore, it can be concluded that in this study a strong R2 value is R2 on the variables of entrepreneurial attitudes and entrepreneurial intentions.

There are two hypotheses rejected in this study, namely hypothesis 6 and hypothesis 7. Hypothesis 6 shows that there is a positive relationship between entrepreneurial education and self-efficacy. Testing of hypotheses carried out on hypothesis 6 shows that hypothesis 6 is not supported or rejected. This result is different from the results of previous research which states that entrepreneurship education and self-efficacy have a positive relationship (Kilenthong, Hills, and Monllor, 2008; and Oyugi, 2016). There are two reasons why hypothesis 6 is rejected. The first reason for rejecting hypothesis 6 is that students' self-efficacy is their confidence that they can successfully open their own business. This is rooted in their capabilities and expertise (Hattab, 2014, 14). This may be due to a deficiency in curriculum design that does not fit the topic with the skills that students feel need, for example there are still many theoretical subjects in the entrepreneurship study program rather than practice. The second reason for rejecting hypothesis 6 can be seen from the results of previous research (Hattab, 2014; Koenig, 2016). Based on research conducted by Hattab (2014), there is no relationship between entrepreneurial education and self-efficacy. Koenig's (2016) research results also show that entrepreneurial teaching has no effect on entrepreneurial self-efficacy.

Hypothesis 7 is the second hypothesis that was rejected in this study. Testing hypothesis 7 which states that there is a relationship between mentoring and self-efficacy, shows the results that the hypothesis is not supported. There are two reasons why this 
hypothesis is not supported. First, judging from the profile of respondents in this study, the majority of respondents in this study were men. Men and women differ in how to view and build a relationship. Based on the theory of self-development and women's career, relationships are considered more important by women than men (Gallos, 1989). Bower (1985, in Ragins and Scandura, 1994) revealed that based on his research, women viewed mentoring as an important part of their career development. Women expect and receive greater benefits in mentoring relationships than women than men. Mentoring relationships show more influence for women not only because mentoring meets their developmental needs (relationships) but also because expectations of the mentoring role are more in line with expectations of women's roles (Ragins and Scandura, 1994, 960). Furthermore, the essence of mentoring is to help mentee and pay attention to its development. This behavior is more in line with the expectations of women's roles than men (Eagly, 1987 in Ragins and Scandura, 1994). In other words, the theory states that mentoring relationships have more influence on women than men. Therefore, hypothesis 7 is not supported.

Conclusion, Limitation, and Suggestion for Future Research.Based on the results of the study it can be concluded that (1) there is a positive relationship between entrepreneurial education and student entrepreneurial intentions, (2) there is a positive relationship between entrepreneurial education and student entrepreneurship attitudes, (3) there is a positive relationship between entrepreneurial attitudes and student entrepreneurial intentions, (4) there is a positive relationship between entrepreneurial education and subjective norms of students, and (5) there is a positive relationship between subjective norms and student entrepreneurial intentions.

This study has limitations in the use of non-probability sampling techniques so that the results of the study cannot be generalized. Therefore, the suggestion for further research is that further research is expected to use probability sampling techniques so that each member in the population has the same probability to be included as research respondents. By using a probability sampling technique, the results of the research research conducted are expected to be generalizable.

\section{REFERENCES}

Adnyana, I. L., \& Purnami, N. M. (2016). "Pengaruh Pendidikan Kewirausahaan, Self Efficacy dan Locus of Control Pada Niat Berwirausaha". E-Jurnal Manajemen Unud, 5(2), 1160-1188.

Ajzen, I. (2005). Attitudes, Personality, and Behavior. Milton-Keynes, England: McGrawHill.

Ajzen, I. (2012). The Theory of Planned Behavior. (P. A. Lange, A. W. Kruglanski, \& E. T. Higgins, Eds.) Handbook of Theories of Social Psychology, 1, 438-459.

Ajzen, I. (2015). "Consumer Attitudes and Behavior: The Theory of Planned Behavior Applied to Food Consumption Decisions". Rivista di EconomiaAgraria, 70(2), 121-138.

Arasti, Z., Falavarjani, M. K., \& Imanipour, N. (2012). “A Study of Teaching Methods in Entrepreneurship Education for Graduate Students". Higher Education Studies, 2(1), 2-10. 
Astuti, R. D., \& Martdianty, F. (2012). “Students' Entrepreneurial Intentions by Using Theory of Planned Behavior (The Case in Indonesia)". The South East Asian Journal of Management, 6(2), 100-112.

Azizah, N., Siregar, S., \&Sudiarti, S. (2017).“EfektifitasPendidikanKewirausahaandan Self Efficacy TerhadapMinatBerwirausaha”. Al-Mu'amalat, 2(II), 427-446.

Azwar, B. (2013). "Analisis Faktor-faktor yang Mempengaruhi Niat Kewirausahaan (Studi Terhadap Mahasiswa Universitas Islam Negeri SUSKA Riau)". Menara, 12(1), 12-22.

Badan Pusat Statistik. (2017). Tingkat Pengangguran Terbuka Menurut Pendidikan Tertinggi yang Ditamatkan.Diakses pada 10 Agustus 2017, dari Badan Pusat Statistik: https://www.bps.go.id.

Bandura, A. (2012). "On the Functional Properties of Perceived Self-Efficacy Revisited". Journal of Management, 38(1), 9-44.

Barringer, B. R., \& Ireland, D. (2015). Entrepreneurship: Successfully Launching New Ventures. Essex, England: Pearson Education Limited.

Bayley, H., Chambers, R., \& Donovan, C. (2016). The Good Mentoring Toolkit for Healthcare. Radcliffe Publishing.

Blumberg, B. F., Cooper, D. R., \& Schindler, P. S. (2014). Business Research Methods.McGraw-hill Education.

Borasi, R., \&Finnigan, K. (2010) "Entrepreneurial attitudes and behaviors that can help prepare successful change-agents in education".The New Educator, 6(1), 1-29.

Budy, D. A. (2017). "Pengaruh Pendidikan Kewirausahaan dan Motivasi Kewirausahaan Terhadap Keterampilan Berwirausaha Mahasiswa Universitas 17 Agustus 1945 Jakarta". Journal for Business and Entrepreneur Jurnal Online Nasional dan Internasional Universitas 17 Agustus 1945, 1(1), 7-222.

Bruce, M., \& Bridgeland, J. (2014). The Mentoring Effect: Young People's Perspectives on the Outcomes and Availability of Mentoring. Washington, D.C.: Civic Enterprises with Hart Research Associates for MENTOR: The National Mentoring Partnership.

Chimucheka, T. (2013). "The Impact of Entrepreneurship Education on the Establishment and Survival of Small, Micro and Medium Enterprises (SMMEs)". J Economics, 4(2), 157-168.

Cooper, S.Y. \& Lucas, W.A. (2006)."Enhancing Self-efficacy for Entrepreneurship and Innovation: An Educational Approach".Entrepreneurial Education. Regional Frontiers of Entrepreneurship Research, 667-688.

DeFreitas, S. C., \& Bravo Jr, A. (2012). "The Influence of Involvement With Faculty And Mentoring on The Self-Efficacy and Academic Achievement of African American And Latino College Students". Journal of the Scholarship of Teaching and Learning, 12(4), 1-11

Eagly, A. H. (1987). Sex Differences in Social Behavior: A Social-Role Interpretation. Hillsdale, NJ: Erlbaum.

Entrialgo, M. \& Iglesias, V. (2016) "The Moderating Role of Entrepreneurship Education on The Antecedents of Entrepreneurial Intention". Entrepreneurship and Management Journal, 1-24.

Fatoki, O. (2014) "The Entrepreneurial Intention of Undergraduate Students in South Africa: The Influences of Entrepreneurship Education and Previous Work Experience”. Mediterranean Journal of Social Sciences, 5(7), 294-299. 
Federal Aviation Administration. (2008). Best Practices for Mentoring in Flight Instruction.

Feist, G. J., Feist, J., \& Roberts, T.-A. (2013). Theories of Personality. Singapore: McGraw Hill Education.

Feldman, M. D., Arean, P. A., Marshall, S. J., Lovett, M., \& O’Sullivan, P. (2010) "Does Mentoring Matter: Results From A Survey of Faculty Mentees at a Large Health Sciences University". Medical education online, 15(1), 5063.

Flood, M. J. (2012). Mentoring and Self-Efficacy in Female Undergraduate Business Students (Doctoral dissertation, The Ohio State University).

Gallos, J. V. (1989). Exploring women's development: Implications for career theory, practice and research. In M. B. Arthur, D. T. Hall, \&B. S. Lawrence (Eds.), Handbook of career theory: 110-132. Boston: Cambridge University Press.

Gunadi, A. P., \& Sihombing, S. O. (2015) "Prediksi Penggunaan Aktual E-Toll Card dengan Pendekatan Persamaan Model Struktural". Jurnal Manajemen Teknologi, 14(2), 151-172.

Hair, J. F. (2015). Essentials of Business Research Methods. United Kingdom: John Wiley \& Sons.

Hair, J. F., Ringle, C. M., \&Sarstedt, M. (2011) "PLS-SEM: Indeed a Silver Bullet". Journal of Marketing theory and Practice, 19(2), 139-152.

Hajrah, S., B., \& Rahayu, W. (2016) "Effect of Entrepreneurial Education and Economic Conditionof Parents towards an Entrepreneurship Attitudes through the Entrepreneurship Interest". IOSR Journal of Business and Management (IOSR$J B M), 18(6), 105-110$.

Hattab, H. W. (2014) "Impact of Entrepreneurship Education on Entrepreneur Intentions of University Students in Egypt". Journal of Entrepreneurship, 23(1), 1-18.

Hayden, J. (2014). Introduction to Health Behavior Theory. USA: Jones \& Bartlett Publishers.

Hayes, E. F. (1998) "Mentoring and Nurse Practitioner Student Self-Efficacy". Western Journal of Nursing Research, 20(5), 521-535.

Hidayah, T. (2015). "Analisis Faktor-Faktor yang Memengaruhi Minat/ Intensi Kewirausahaan Mahasiswa STIE Mandala Jember". Jurnal Relasi STIE Mandala, $16(1)$.

Hussain, A., \& Norashidah. (2015). "Impact of Entrepreneurial Education on Entrepreneurial Intentions of Pakistani Students". Journal of Entrepreneurship and Business Innovation, 2(1), 43-53.

Indarti, N., \& Rostiani, R. (2008). "Intensi Kewirausahaan Mahasiswa: Studi Perbandingan Antara Indonesia, Jepang dan Norwegia". Jurnal Ekonomi dan Bisnis Indonesia, 23(4).

Ismail, A., Abdullah, N. A., Zaiedy, N. I., Ghani, A., \& Omar, N. (2015)."Mentoring Program as an Instrument of Enhancing Mentees' SelfEfficacy". ActaUniversitatisDanubius.Communicatio, 9(1).

Jain, R., Chaudhary, B., \& Jain, N. (2016)."Impact of Mentoring on Academic Performance \& Career Self-efficacy of Business Students". Indian Journal of Industrial Relations, 51(4), 684-694.

Jaya, I. P. B. A., \&Seminari, N. K. (2016)."Pengaruh Norma Subjektif, EfikasiDiri, danSikapTerhadapIntensiBerwirausahaSiswa SMKN Di Denpasar". $E$ JurnalManajemenUniversitasUdayana, 5(3). 
Jnah, A. J., \& Robinson, C. B. (2015). "Mentoring and Self-Efficacy: Implications for the Neonatal Nurse Practitioner Workforce". Advances in Neonatal Care, 15(5), E3E11.

Jr, McDaniel, Carl, Gates, \& Roger.(2014). Marketing Research. USA: John Wiley \& Sons.

Karimi, S., Biemans, J. A., Lans, M. H., \& T., M. C. (2016). "Effects of Role Models and Gender on Students' Entrepreneurial Intentions". Journal of Small Business Management, 54(1), 187-209.

Kilenthong, P., Hills, G., \&Monllor, J. (2008). “Impact of Entrepreneurship Education on Entrepreneurial Self-Efficacy and Intention (Summary)". Frontiers of Entrepreneurship Research, 28(4), 11.

Kim-Soon, N., Ahmad, A. R., \& Ibrahim, N. N. (2014). "Entrepreneurial Motivation and Entrepreneurship Career Intention: Case at a Malaysian Public University". Crafting Global Competitive Economies: 2020 Vision Strategic Planning \& Smart Implementation, 1001-1011.

Koenig, L. S. (2016). "Integrating Entrepreneurial Self-Efficacy into Education at Universities". Ekonomskivjesnik/Econviews-Review of Contemporary Business, Entrepreneurship and Economic Issues, 29(2), 311-321.

Kram, K. E., \& Isabella, L. A. (1985).Mentoring alternatives: The role of peer relationships in career development. Academy of management Journal, 28(1), 110132.

Kusmintarti, A. (2016). "Karakteristik Wirausaha Memediasi Pengaruh Pendidikan Kewirausahaan Terhadap Sikap Kewirausahaan". 7th Industrial Research, Workshop, and National Seminar (138-146). Bandung: Politeknik Negeri Bandung.

Kusmintarti, A., Riwajanti, N. I., \& Asdani, A. (2017). "Sikap Kewirausahaan Memediasi Pengaruh Pendidikan Kewirausahaan Terhadap Intensi Kewirausahaan”. Jurnal Riset dan Aplikasi: Akuntansi dan Manajemen, 2(4), 45-54.

Liñán, F. (2004). “Intention-based Models of Entrepreneurship Education”. Piccolla Impresa/Small Business, 3(1), 11-35.

Ljungberg, I., Kroll, T. Libin, A. \& Gordon, S. (2011). ”Using Peer Mentoring for People With Spinal Cord Injury to Enhance Self-Efficacy Beliefs and Prevent Medical Complications", Journal of Clinical Nursing, 20(3-4), 351-358

Mahyarni. (2013). "Theory of Reasoned Action dan Theory of Planned Behavior (Sebuah Kajian Historis tentang Perilaku". Jurnal EL-RIYASAH, 4(1), 13-23.

Mamuasi, R. (2017)."Kontribusi Pembelajaran Kewirausahaan Terhadap Pembentukan Sikap Kewirausahaan”. JurnalPendidikan, 11(1), 36-41.

Maskur, A., Tjahjaningsih, E., \& Saeroji, A. (2015). "Pengaruh Norma Subjektif Dan Kontrol Perilaku Yang Dipersepsikan Terhadap Niat Pinjam KUR Mikro". Proceeding SENDI_U.

McBurney, D. H., and White, T. L. (2009). Research Methods, 8th ed. United States of America: Wadsworth Cengage Learning.

Michael, A. (2008). Mentoring and Coaching, The Chartered Institute of Management Accountants. London.

Monecke, A., \&Leisch, F. (2012). SemPLS: Structural Equation Modeling Using Partial Least Squares. 
Mwiya, B., Wang, Y., Shikaputo, C., Kaulungombe, B., \& Kayekesi, M. (2017). "Predicting the Entrepreneurial Intentions of University Students: Applying the Theory of Planned Behaviour in Zambia, Africa". Open Journal of Business and Management, 5, 592-610.

Naia, A., Baptista, R., Biscaia, R., Januário, C., \&Trigo, V. (2017). "Entrepreneurial intentions of Sport Sciences students And Theory of Planned Behavior". Motriz: Revista de EducaçãoFísica, 23(1), 14-21.

Neal, T. I. (2008). Mentoring, Self-efficacy and Nurse Practitioner students: A modified Replication. Ball State University.

Nugroho, T. R., Setyariningsih, E., Kasnowo, \& Setiono, H. (2017) "Pengaruh Pendidikan Kewirausahaan Terhadap Sikap Kewirausahaan Mahasiswa". Jurnal JP3, 7(2).

Oyugi, J. L. (2016). The Mediating Effect of Self-Efficacy on The Relationship Between Entrepreneurship Education and Entrepreneurial Intentions of University Students.

Pramudianto. (2015). I'm a C oach: StrategiM engembangkanP otensiD iridengan coaching. Yogyakarta: CV ANDI OFFSET.

Prihantoro, W. S., \& Hadi, S. (2016). "Pengaruh Pendidikan Kewirausahaan, Motivasi Berwirausaha dan Lingkungan Keluarga Terhadap Sikap Mental Kewirausahaan". Economic Education Analysis Journal, 5(2), 705-717.

Ragins, B. R., \&Scandura, T. A. (1994). "Gender Differences in Expected Outcomes of Mentoring Relationships". Academy of management Journal, 37(4), 957-971.

Rustika, I. M. (2012). "Efikasi Diri: Tinjauan Teori Albert Bandura". Buletin Psikologi Fakultas Psikologi Universitas Gadjah Mada, 20(1), 18-25.

Sabah, S. (2016). "Entrepreneurial Intention: Theory of Planned Behaviour and the Moderation Effect of Start-Up Experience". Entrepreneurship: Practice-Oriented Perspectives.

Santi, N., Hamzah, A., \& Rahmawati, T. (2017). "Pengaruh Efikasi Diri, Norma Subjektif, Sikap Berperilaku, dan Pendidikan Kewirausahaan Terhadap Intensi Berwirausaha". Jurnal Inspirasi Bisnis dan Manajemen, 1(1), 63-74.

Santosa, M., \& Natsir, M. (2015). "Pengaruh Mentoring Terhadap Efikasi Diri Kewirausahan". MADIC. Semarang.

Schiffman, L. G., \& Wisenblit, J. (2015). Consumer Behavior. Pearson.

Schwarz, N. (2007). "Attitude construction: Evaluation in context". Social cognition, 25(5), 638-656.

Sekaran, U., \&Bougie, R. (2013). Research Methods for Business: A skill building approach.John Wiley \& Sons.

Setiawan, J. L. (2014)."Examining Entrepreneurial Self-efficacy Among Students". Procedia-social and behavioral sciences, 115, 235-242.

Sugiyono. (2014). MetodePenelitianKuantitatif, Kualitatifdan $R \&$ D. Bandung: Alfabeta.

Sulung, N. (2016). "Efektifitas Metode Preseptor dan Mentor Dalam Meningkatkan Kompetensi Perawat Klinik". Jurnal IPTEKS Terapan: Research of Applied Science and Education, 9(2), 224-235.

Utami, C. W. (2017). "Attitude, Subjective Norms, Perceived Behavior, Entrepreneurship Education and Self-efficacy toward Entrepreneurial Intention University Student in Indonesia". European Research Studies, 20(2), 475.s

Valerio, A., Parton, B., Robb, A. (2014). Entrepreneurship Education and Training Programs around the World: Dimensions for Success. Washington, DC: World Bank. 
Wach, K., \& Wojciechowski, L. (2016). "Entrepreneurial Intentions of Students in Poland in the View of Ajzen's Theory of Planned Behaviour". Entrepreneurial Business and Economics Review, 4(1), 83-94.

Weber, S., Oser, F. K., Achtenhagen, F., Fretschner, M., \& Trost, S. (2014). Becoming an Entrepreneur. Rotterdam, Netherlands: Sense Publishers.

Wedayanti, N. P., \& Giantari, G. A. (2016). "Peran Pendidikan Kewirausahaan dalam Memediasi Pengaruh Norma Subyektif Terhadap Niat Berwirausaha". E-Jurnal Manajemen Unud, 5(1), 533-560.

Wibowo, S., \& Pramudana, K. A. S. (2016)."Pengaruh Pendidikan Kewirausahaan Terhadap Intensi Berwirausaha yang Dimediasi oleh Sikap Berwirausaha".EJurnal Manajemen Unud, 5(12), 8167-8198.

Yaqub, M. K., Mufti, N. A., Ali, S., \& K haleeq, M. U. (2015). "Impact of Entrepreneurship Education on Attitudes of Students Towards Entrepreneurship". Journal of Basic and Applied Sciences, 11, 590-595.

Zhang, Y., Duysters, G., \& Cloodt, M. (2014). "The Role of Entrepreneurship Education as a Predictor of University Students' Entrepreneurial Intention". International Entrepreneurship and Management Journal, 10(3), 623-641.

Zikmund, W.G, \&Babin, B.J. (2015).Essentials of Marketing Research. USA: Cengage Learning. 